\title{
INTERACTIONAL METADISCOURSE USED IN BLOOMBERG INTERNATIONAL DEBATE
}

\author{
Riski Istiani $^{1}$, Dian Puspita ${ }^{2}$ \\ Universitas Teknokrat Indonesia ${ }^{1,2}$
}

riskiistiani11@gmail.com¹,dian.puspita@teknokrat.ac.id ${ }^{2}$

\begin{abstract}
In delivering an argument, several things must be known, such as the theme, the purpose, and the content of the argument in a debate. Since debate demands critical thinking, debaters need to consider their words' choice in delivering their argument. In that case, this research aims to analyze the uses of interactional metadiscourse markers that are applied in the Bloomberg International Debate. In doing the analysis, the writers used the descriptive method and proposed Hyland's theory (2005). As the result of the research, it shows that the most speaker who is producing interactional metadiscourse markers is Ella Cox, followed by John Allan and then Ndidie Okezie and finally Auday and Rus Ma. Although there are three speakers in each team (both proposition and opposition), it seems that the third person on each team only as support and the one who then summarizes the result of the debate for each team. Further, related to the uses of interactional metadiscourse, the most used of the interactional dimension markers is self-mention, followed by booster, hedges, and booster.
\end{abstract}

Keywords: Bloomberg, critical thinking, debate, interactional metadiscourse, metadiscourse markers

\section{INTRODUCTION}

Debate is an activity of having an argument as a process of inquiry and advocacy either individually or in groups that provide reasoned argument to support for and against a proposition (Freeley \& Steinberg, 2013). Commonly, in the field of law courts and legislative bodies, a debate is used as media to reach decisions (Freeley \& Steinberg, 2013). However, recently the writers noticed that debate is not only used for formal purposes but also used a medium for competition, both national and international. Thus, regarding the phenomenon, the writers in this research are interested in examining a debate show in the Bloomberg International Debate. Here, the writers find debate as an interesting topic since the debaters always provide and give opinions or arguments for every proposition.

In delivering an argument, several things must be aware, such as the theme, the purpose, and the content of the argument in a debate. Also, since debate demands critical thinking, debaters need to consider their words' choice in delivering their argument. The understanding of each other's arguments is, even in a debate, is needed in the process of interaction (Fitri \& Qodriani, 2019). It is in accordance with the function of language to communicate ideas and desires (Rido, 2020). In that case, this research aims to analyze the issue by dealing with the aspect of debaters' language during giving arguments. The writers address issues such as the type and function of every word that was uttered by debaters during argumentation. Therefore, to analyze that kind of issue, a study of interactional metadiscourse markers can be applied. In addition, we can see the characteristic of the language used to pose the arguments (Unggul \& Gulö, 2017).

Metadiscourse mostly focuses on written language but there are kinds of phenomena in spoken language that can be found and analyzed in metadiscourse, such as language gender, political debates, and many others (Hyland, 2005). Thus, regarding the explanation, it can be said that commonly, metadiscourse is a study that focuses on written language. However, it does not mean that metadiscourse does not analyze spoken language. Metadiscourse also can be used as a tool to analyzed language gender, political debates, and many more (Afrianto \& Inayati, 2019).

Furthermore, metadiscourse is divided into two broad categories, they are interactive metadiscourse and interactional metadiscourse (Hyland, 2005). The interactive metadiscourse centers on the content of the text, while the interactional focus on the participants of the interaction (Zareifard \& Alinezhad, 2014). Thus, since this research focuses on the argument of debaters, which every argument shows the interaction among the debaters, the writers noticed that interactional metadiscourse can be applied to analyzed the debate. It is in accordance with the concern of interactional metadiscourse which is the way writers or speakers conduct interaction by intruding 
and commenting on their message (Kuswoyo \& Siregar, 2019). Therefore, in this analysis, the writers are interested in analyzing interactional metadiscourse in a debate to explore the metadiscourse markers employed by the debaters in the Bloomberg International Debate with the topic "Is Education the Most Important Factor in Achieving a Diverse Business Environment?".

Interestingly, the study of metadiscourse has been discussed by many scholars such as (Mina \& Biria, 2017) who identify interactive and interactional metadiscourse in a targeted sample of 100 English research articles written by an Iranian writer utilizing Hyland's taxonomy. As a result, the Iranian writer used hedges, boosters, and self-mention more frequently in medical science articles compared to those in social sciences. (Salichah et al, 2015 ) investigated the use of hedges and boosters which are important in academic writing discourse as a means of communicative strategies for increasing or reducing the force of the statement. The finding indicates that students used hedges more than boosters in their research articles as a way of reducing the risk of opposition, as a means of being polite and as a way to obscure their authorial identity while advancing their opinion. Sari examined and explained the function of interpersonal metadiscourse markers used in Michele Obama's speech. The result of the research shows that both interactive and interactional metadiscourse is applied in Michele Obama's speech (2014)

Accordingly, metadiscourse is considered as a new concept in fields of discourse analysis and language education (Mirshamsi \& Allami, 2013). Further, this research aimed to describe the types of interactional metadiscourse markers and their function used by the debaters in Bloomberg International Debate. Also, this research is expected to give readers new knowledge about the overview of metadiscourse, especially how to apply the interactional one in debate as a form of verbal text.

\section{METHOD}

To do the analysis, the writers employed Hyland's metadiscourse theory. Metadiscourse is recognized as an important means of facilitating communication, supporting a writer's position, and building a relationship with an audience (Hyland \& Tse, 2004). Metadiscourse also defined as discoursing about spoken or written discourse which provides readers or listeners with direction rather than information (Crismore et al, 1994; Ädel, 2006). However, metadiscourse is defined as the interpersonal resources used to organize discourse or a writer's stance toward either its content or the reader (Hyland, 2015). In that case, the study of metadiscourse reminds us that statements do not just have an orientation to the world outside of the text, but simultaneously orientate to the readers' understanding of that world through the text itself.

Metadiscourse allows readers to understand discourse texture and intertextuality, to share pragmatic presuppositions (Kuswoyo \& Susardi, 2018), to infer intended meanings, and to interpret the institutional and ideological ties underlying the text (Pérez-Llantada, 2003) and it facilitates the reconstruction of writer's writing plan by readers and helps readers create and affirm expectations about the text (Crismore in Hashemi \& Golparvar, 2012).

Here, the study of metadiscourse can be analyzed both in written and spoken form. Thus, (Hyland, 2005) distinguishes the model of metadiscourse into two categories, they are interactive and interactional metadiscourse. The interactive metadiscourse centers on the content of the text, while the interactional focus on the participants of the interaction (Zareifard \& Alinezhad, 2014). Both interactive and interactional resources being as two interrelated modes of interaction (Thompson, 2001). However, since this research focused on analyzing interactional metadiscourse, the writers only described the markers of interactional metadiscourse based on (Hyland, 2005) which the model of the metadiscourse can be noticed as follow:

Table 1. Hyland's Model of Interactional Metadiscourse (2005: 49)

\begin{tabular}{|l|l|l|}
\hline \multicolumn{2}{|c|}{ Interactional Resource Involve the Reader in the Text } \\
\hline \multicolumn{1}{|c|}{ Category } & \multicolumn{1}{|c|}{ Function } & \multicolumn{1}{|c|}{ Keywords } \\
\hline Hedges & $\begin{array}{l}\text { Withhold writer's full commitment } \\
\text { to the proposition }\end{array}$ & Might/perhaps/possible/about \\
\hline Boosters & $\begin{array}{l}\text { Emphasize force or the writer's } \\
\text { certainty in the proposition }\end{array}$ & In fact/definitely/it is clear that \\
\hline Attitude markers & $\begin{array}{l}\text { Express the writer's attitude to the } \\
\text { proposition }\end{array}$ & $\begin{array}{l}\text { Unfortunately/I } \\
\text { agree/surprisingly }\end{array}$ \\
\hline
\end{tabular}




\begin{tabular}{|l|l|l|}
\hline Engagement & $\begin{array}{l}\text { Explicitly refer to or build a } \\
\text { relationship with the reader }\end{array}$ & $\begin{array}{l}\text { Consider/note that/you can see } \\
\text { that }\end{array}$ \\
\hline Self-mention & Explicit reference to the author(s) & I/we/my/our \\
\hline
\end{tabular}

Hyland (2005) explained that the interactional metadiscourse concerns on the ways a writer conducts an interaction by intruding and commenting on their message. As it is seen from the table 1., those features are metadiscourse markers that are mentioned by Hyland to involve readers and open opportunities for them to contribute to the discourse by alerting them to the author's perspective towards both propositional information and readers themselves.

\section{A. Hedges}

Hedges are devices such as possible, might, and perhaps, which indicate a writer's decision to recognize alternative voices and viewpoints and so withhold complete commitment to a proposition (Hyland, 2005). Hyland (2005) also stated that "the use of hedges enables the writer to express a perspective on their statements, to present unproven claims with caution and to enter to a dialogue with their audience." Example: And for me, this is personal because my story would not be possible without this city (Sari, 2014).

\section{B. Boosters}

Boosters as a tool that serves to strengthen the claim to show a writer's commitment and can be used as a means of commitment to the truth value of the proposition (Hyland, 1988). The function of boosters is to increase the force of assertions, medium to create interpersonal solidarity with readers (Hyland, 2005). Example: It is certainly a pleasure to be here with all of you today (Sari, 2014).

\section{Attitude Markers}

Attitude markers express a writer's attitude to propositional content, conveying surprise, obligation, agreement, and importance (Hyland, 2005). Hyland (2005) also explained that "these markers are realized in deontic verbs (should, have to), attitudinal adverbs, adjectival constructions, and cognitive/mental verbs which instead of commenting on the status of information, its probable relevance, reliability or truth, attitude markers convey surprise, agreement, importance, obligation, frustration, and so on." Example: Unfortunately, the level of health is very low among agers in Iran (Zareifard \& Alinezhad, 2014).

\section{Self-Mentions}

Self-mentions refers to the degree of explicit author presence in the text measured by the frequency of firstperson pronouns and possessive adjectives (such as I, me, mine, exclusive we, our, ours) (Hyland, 2005). Selfmentions suggest the extent of author presence in terms of first-person pronouns and possessives and it also reflects the degree of author presence in terms of the incidence of first-person pronouns and possessives (Hyland, 2005). Example: We are so very proud of you (Sari, 2014)

\section{E. Engagement Markers}

Engagement Markers are devices that explicitly address readers, either to focus their attention or include them as discourse participants. It explicitly addresses readers, either by selectively focusing their attention or by including them as participants in the text through second-person pronouns, imperatives, question forms, and asides (Hyland, 2005). Example: And as business leaders, you all know that this city's young people are your future workers, your future customers (Sari, 2014).

\section{FINDINGS AND DISCUSSION}

The research analyzed the interactional metadiscourse markers in Bloomberg International Debate with the topic "Is Education the Most Important Factor in Achieving a Diverse Business Environment?" which was held on Bloomberg. In the analysis, the writers focus on the speakers or the debaters, since all of them show different argumentation that leads to another idea. These kinds of arguments are also used by the debaters to answer the question that is given by other debaters. Hence, in producing their arguments, they will produce different kinds of interactional metadiscourse that also have a different function. 


\section{Hedges}

\section{Might}

Table 2 The Finding on marker "Might"

\begin{tabular}{|l|l|}
\hline \multicolumn{1}{|c|}{ Speaker } & \multicolumn{1}{c|}{ Utterance } \\
\hline $\begin{array}{l}1^{\text {st }} \text { Opposition } \\
\text { Speaker }\end{array}$ & $\begin{array}{l}\text { This shows that we have severe problems in the education system that we } \\
\text { might } \text { not be able to fix. In the next few years, it might take us decades to } \\
\text { fix these problems... }\end{array}$ \\
\hline
\end{tabular}

Table 2 shows that the metadiscourse marker that is used by the speaker is the word "might". Here, the speaker comes from the opposition and according to the speaker, the hedges "might" be used to show two issues. The first is the issue of education system that is probably cannot be fixed and secondly, even though the problem of educational system can be fixed, it might take a very long time (indicated by the word "decades" by the speaker). Here, the use of the word "might" as the interactional metadiscourse of hedges on the sentences above is showing uncertainty. In other words, the hedges "might" in this case show the function as information to give an opinion rather than fact. Here, the speaker tries to give the audience and other speakers their judgment from their point of view by seeing this kind of constrain of beneficial growth.

\section{Booster}

\section{Truth}

Table 3 The finding on marker "Truth"

\begin{tabular}{|l|l|}
\hline \multicolumn{1}{|c|}{ Speaker } & \multicolumn{1}{c|}{ Utterance } \\
\hline $\begin{array}{l}1^{\text {st }} \text { Proposition } \\
\text { Speaker }\end{array}$ & $\begin{array}{l}\text { In today's debate, we face an incontrovertible truth that education is the } \\
\text { passport to prosperity. }\end{array}$ \\
\hline
\end{tabular}

As seen from table 3, the metadiscourse marker used by the speaker is "truth" which in this case, the speaker comes from the proposition. Here, the speaker used booster from the word "truth" to explain to the audience and also other debater participants about the reality that happened recently based on his perspective that education is the passport to prosperity. The speaker uses the maker "truth" to boost or strengthen his opinion about his argument that education is the most important thing to reach prosperity. In other words, the booster from the word "truth" has the function to strengthen an argument by leading the audience to draw a similar conclusion as the speaker.

\section{In Fact}

\begin{tabular}{|l|l|}
\multicolumn{1}{|c|}{ Table 4 The finding on marker "In Fact" } \\
\hline \multicolumn{1}{|c|}{ Speaker } & \multicolumn{1}{c|}{ Utterance } \\
\hline $\begin{array}{l}2^{\text {nd }} \text { Proposition } \\
\text { Speaker }\end{array}$ & $\begin{array}{l}\text { In fact }, \text { with all the us-and-them rhetoric that is so prevalent across our } \\
\text { society today, ... is in fact the only way we will ever truly deliver on that } \\
\text { vision. }\end{array}$ \\
\hline
\end{tabular}

The table 4 above shows that the speaker is using a different booster that is "in fact" twice to support the previous speaker (from proposition) which is they believed that the truth that education is the ground or the basic thing that lay on the very groundwork business world is a fact. In that case, the function of the booster in the word "in fact" from the utterance has function to strengthen the speaker's argument by leading the audience to draw the same idea as the speaker.

\section{Of Course}

Table 5 The finding on marker "Of Course"

\begin{tabular}{|l|l|}
\hline \multicolumn{1}{|c|}{ Speaker } & \multicolumn{1}{|c|}{ Utterance } \\
\hline $\begin{array}{l}1^{\text {st }} \text { Opposition } \\
\text { Speaker }\end{array}$ & $\begin{array}{l}\text { That's not something we're going to disagree with, of course there are } \\
\text { discrepancies in recruitment. }\end{array}$ \\
\hline
\end{tabular}


The next booster that is used by speakers is the word "of course" which in this case, this booster is mentioned by two speakers, the first from the opposition and secondly from the proposition. However, regarding the metadiscourse markers, both of them are having a similar function, which is strengthening the speaker's argument so that the speaker can lead the audience to get into the speaker's perspective. The only difference is the topic that they are delivered for both debaters and audience. In this case, the speaker is talking about discrepancies or differentiation in recruitment for some factors when people go to the same recruitment process.

\section{Very Clear}

\begin{tabular}{|l|l|}
\multicolumn{1}{c}{ Table 5 The finding on marker "Very Clear" } \\
\hline \multicolumn{1}{|c|}{ Speaker } & \multicolumn{1}{c|}{ Utterance } \\
\hline $\begin{array}{l}1^{\text {st }} \text { Proposition } \\
\text { Speaker }\end{array}$ & $\begin{array}{l}\text { Our definition today is very clear we think that in the school system where } \\
\text { the primary, ... }\end{array}$ \\
\cline { 2 - 3 } & $\ldots$...and so, our case actually today is very clear; how do we make it so... \\
\hline
\end{tabular}

Based on table 5, there the speaker is using booster "very clear" twice. First, it is used to give his argument about the importance education which in this case, it described as the school system on the primary, secondary or tertiary that is developing both important skills and technical skills. Further, on the second argument, the speaker is giving his supporting idea of how important education for the business world since in this case, he brings the matter of Asia and Africa which is alluded from the opposition's speaker. Here, the metadiscourse marker has the function to strengthen the arguments so that he can lead the audience so they can have a similar thought or idea with the speaker which the ideas are from the combination from two arguments that is about the importance of the educational system.

\section{Attitude Markers}

\section{Agree}

\begin{tabular}{|c|c|}
\hline Speaker & Utterance \\
\hline $\begin{array}{l}1^{\text {st }} \text { Opposition } \\
\text { Speaker }\end{array}$ & $\begin{array}{l}\text { On side opposition today, we also agree that education is extremely } \\
\text { important, but what side proposition is missing out on is that alone education } \\
\text { cannot achieve diversity. }\end{array}$ \\
\hline
\end{tabular}

On table 6 above, it shows that the metadiscourse markers that are used by the speaker are in the word "agree". Here, through the attitude markers, the speaker is telling about her argument that both her team and herself personally agree that education is extremely important which in this case, the speaker agrees with the argument from the proposition team that education is important for society and business world. In this case, the markers which are used by the speaker have a function to demonstrate an agreement.

\section{Totally}

Table 7 The finding on marker "totally"

\begin{tabular}{|l|l|}
\hline \multicolumn{1}{|c|}{ Speaker } & \multicolumn{1}{c|}{ Utterance } \\
\hline $\begin{array}{l}2^{\text {nd }} \text { Opposition } \\
\text { Speaker }\end{array}$ & Everyone on our side of the argument totally accepts that point... \\
\hline
\end{tabular}

Based on table 7 above, the markers still from the attitude markers, only this time, it comes from the word "totally". Here, the agreement based on his utterance is that the speaker and his team agree with the argument or idea from the proposition team where they admit that education is important and vital. Further, the writers found that the function of this marker also similar to the previous data that is to show an agreement of an argument or opinion. 


\section{Self-Mention}

\section{I}

Table 8 The finding on marker "I"

\begin{tabular}{|c|l|}
\hline Speaker & Utterance \\
\hline $1^{\text {st }}$ Proposition Speaker & On that basis, $\boldsymbol{I}$ beg to propose, thank you. \\
\hline
\end{tabular}

In the interactional metadiscourse markers of self-mention, the writers found almost from each of the speakers. In that case, the writers only put one example datum that is related to each marker since the function is similar. Here, the most used marker by the speaker that the writers found is from the word "I". As seen from table 4.8 , the example of the datum is taken from the proposition speaker which in this case, the speaker uses it after he finished delivering the argument. As the function of this marker, it is used to explicit reference to the author, which means that the marker of "I" shows the reference to the speaker herself which refers to the speaker from the proposition.

\section{We}

Table 9 The finding on marker "We"

\begin{tabular}{|l|l|}
\hline \multicolumn{1}{|c|}{ Speaker } & \multicolumn{1}{c|}{ Utterance } \\
\hline $1^{\text {st }}$ Proposition & $\begin{array}{l}\text { In today's debate, we face an incontrovertible truth that education is the } \\
\text { Speaker }\end{array}$ \\
\cline { 2 - 3 } & $\begin{array}{l}\text { Our definition today is very clear } \boldsymbol{w e} \text { think that in the school system where } \\
\text { the primary... }\end{array}$ \\
\end{tabular}

Table 9 above shows another marker from the self-mention metadiscourse which is "we". Here, the writers found similar case just like the previous datum that the uses of self-mention "we" is used by most of the speakers, but the only difference is the topic that they bring when they are using this marker. However, the function of this marker is similar for each speaker that is to draw the audience's attention into the argument from the speaker and to shows that the speaker is representing the similarity of ideas or arguments of his team. As seen from the example of the datum above, the speaker from the proposition used the marker of "we" twice in the debate. In this case, the speaker uses this self-mention for two purposes, firstly, the speaker used it to involve the audience to see the fact that education is the key to achieve property and second, to shows the involvement of the speaker and his team of the proposition.

\section{My}

\begin{tabular}{|l|l|}
\hline Speaker & \multicolumn{1}{|c|}{ Table 10 The finding on marker "My" } \\
\hline $\begin{array}{l}1^{\text {st }} \text { Proposition } \\
\text { Speaker }\end{array}$ & $\begin{array}{l}\text { Today } \boldsymbol{m y} \text { partner Ndidi is gonna tell you about the dangers that come with } \\
\text { not emphasizing the importance of Education. } \boldsymbol{M} \boldsymbol{y} \text { partner Rus Ma is gonna } \\
\text { summarize but } \boldsymbol{m y} \text { case is about the technical base... }\end{array}$ \\
\hline
\end{tabular}

The next metadiscourse markers from self-mention that is used by speakers are from the word "my". Here, the writers noticed that this marker also used by more than one speaker so that in this case, the writers only shows one example of many data since the function of this marker is similar that is to indicate the speaker's possessives which in this case, the possessives are in the form of "partner" and "case". However, the only difference from one datum to another is the topic that they bring in using the marker. As seen in Table 4.10, the example shows that the marker of "my" is used to shows the possession of the speaker's partner.

\section{Our}

Table 11 The finding on marker "Our"

\begin{tabular}{|l|l|}
\hline \multicolumn{1}{|c|}{ Speaker } & \multicolumn{1}{|c|}{ Utterance } \\
\hline $\begin{array}{l}1^{\text {st }} \text { Proposition } \\
\text { Speaker }\end{array}$ & $\begin{array}{l}\text { Our definition today is very clear we think that in the school system where } \\
\text { the primary... }\end{array}$ \\
\hline
\end{tabular}


On table 11 above, shows another metadiscourse marker that is used by speakers which still in the field of self-mention that is "our". Similar to the previous data, this marker also used by more than one speaker so that the writers only put one datum example that represents all of them since the function of this marker also similar. In this case, the word "our" also acts as the possessive adjective which in this case, the writers noticed that the speaker is using the self-mention to shows the audience about the topic that his team is going to present about. Further, the function of self-mention in this utterance acts as the possessive adjective that refers not only to himself but also refers to his team as well.

\section{Us}

Table 12 The finding on marker "Us"

\begin{tabular}{|l|l|}
\hline \multicolumn{1}{|c|}{ Speaker } & \multicolumn{1}{c|}{ Utterance } \\
\hline $\begin{array}{l}2^{\text {nd }} \text { Proposition } \\
\text { Speaker }\end{array}$ & $\begin{array}{l}\text { I implore you, therefore, do not let the opposition take } \boldsymbol{u s} \text { backward with } \\
\text { this motion. }\end{array}$ \\
\hline
\end{tabular}

Based on table 12, the metadiscourse marker used by the speakers in the field of self-mention is "us". In this marker, the writers found that it is only uttered by two speakers which come from both opposition and proposition. However, as it similarly shows a similar function, the writers in this case only show one datum example to represent the uses of the marker. Here, the datum shows that the speaker used the word "us" in her utterance to ask the support from the audience that hopefully, they will understand and in line with the objective from the argument of proposition team since the word "us" refers to herself and her team. Thus, the self-mention, in this case, has a function as involving the listener in the speaker's argument.

\section{CONCLUSION}

Based on the findings, the writers conclude that regarding the types of interactional metadiscourse markers, the types of markers that are used by speakers consist of Hedges, Boosters, Attitude Markers, Self-Mention, and Engagement Markers. However, in the process of analyzing the metadiscourse markers of the interactional dimension, the writers did not find the metadiscourse that is related to engagement markers.

In that case, related to the result of the finding, the writers conclude that the most speaker who is producing interactional metadiscourse markers is the first speaker from the opposition team, followed by the second speaker from the opposition team and then the second speaker from the proposition team and finally the first and third speaker from the proposition team. Although there are three speakers in each team (both proposition and opposition), it seems that the third person on each team acts as a support and also the one who summarizes the result of the debate for each team. Further, related to the uses of interactional metadiscourse, the most used of the interactional dimension markers is self-mention, followed by booster, hedges, and booster. Here, the writers do not need to describe all of the exact data findings since most of them (such as self-mention) are showing similar words so that the function is technically similar.

\section{REFERENCES}

Ädel, A. (2006). Metadiscourse in L1 and L2 English. Amsterdam, Netherlands: Benjamins.

Afrianto \& Inayati, A. (2019). Existential process in Harry Potter and the Chamber of Secret: A systemic functional linguistic study. Teknosastik: Jurnal Bahasa dan Sastra, 14(1), 26-31.

Crismore, A., Markkanen, R. \& Steffensen, M.S. (1994). Metadiscourse in Persuasive Writing: A Study of Texts Written by American and Finnish University Students. Written Communication, 10-39.

Fitri, Ernawati \& Qodriani, L. U. (2019). A study on flouting maxims in Divergent novel. Teknosastik: Jurnal Bahasa dan Sastra, 14(1), 32-40.

Freeley, A. J. \& Steinberg, D. L. (2013). Argumentation and debate. U.S: Cengage Learning.

Hashemi, M. R. \& Golparvar, E. (2012). Exploring metadiscourse markers in Persian news reports. International Journal of Social Science Tomorrow, 1(2), 1-6.

Hyland, K. (1998). Hedging in Scientific Research Articles. Amsterdam: John Benjamins.

Hyland, K. (2005). Metadiscourse. London: Continuum. 
Hyland, K. (2015). Metadiscourse.: The International Encyclopedia of Language and Social Interaction, First Edition. Hong Kong: University of Hong Kong.

Hyland, K. \& Tse, P. (2004). Metadiscourse in academic writing: a reappraisal. Applied Linguistics, 25(2), 156-177.

Kuswoyo, Heri \& Siregar, R. A. (2019). Interpersonal metadiscourse markers as persuasive strategies in oral business presentation. Lingua Cultura, 13(4), 297-304.

Kuswoyo, Heri \& Susardi, S. (2018). Thematic progression in EFL students' academic writings: A systemic functional grammar study. Teknosastik: Jurnal Bahasa dan Sastra, 14(2), 39-45.

Mina, G. K. \& Biria, R. (2017). Exploring interactive and interactional metadiscourse markers in discussion sections of social and medical science articles. International Journal of Research in English Education, 2(4), 11-29.

Mirshamsi, A. S. \& Allami, H. (2013). Metadiscourse markers in the discussion/conclusion section of Persian and English master's theses. Journal of Teaching Language Skills, 32(3), 23-40.

Pérez-Llantada, C. (2003). Communication skills in academic monologic discourse: Empirical and applied perspectives. Circulo de Lingüística Aplicada a la Comunicación, 3(15), 1-14.

Rido, Akhyar. (2020). "Why they act the way they do?": Pedagogical practices of experienced vocational english language teachers in Indonesia. International Journal of Language Education, 4(1), 24-37.

Salichah, I., Irawati, E., \& Basthomi, Y. (2015). Hedges and boosters in undergraduate students' research articles. Jurnal Pendidikan Humaniora, 3(2), 154-160.

Sari, Aryati Meiga. (2014). Interactional Metadiscourse Markers Used in Michele Obama's Speech. Semarang: Dian Nuswantoro University.

Thompson, G. (2001). Interaction in academic writing: learning to argue with the reader. Applied Linguistics, 22(1), 58-78.

Unggul, G. Mekaria \& Gulö, Ingatan. (2017). An Analysis of gerund and to infinitive in argumentative essays. Teknosastik: Jurnal Bahasa dan Sastra, 15(1), 1-6.

Zareifard, R. \& Alinezhad, B. (2014). A study of interactional metadiscourse markers and gender in the defense seminars of Persian speakers. Journal of Educational and Social Research, 4(1), 231-231. 